Elżbieta Dryl|

Uniwersytet Warszawski

\title{
Komunikacja werbalna w misterium Kościoła
}

Bo gdzie są dwaj albo trzej zebrani w imię moje, tam i ja jestem (Mt 18, 20).

Postęp technologiczny w dziedzinie środków komunikacji społecznej - nieuchronny i pożądany, jest współcześnie na tyle znaczący, że prowokuje do stawiania pytań o jego ewentualne niekorzystne następstwa. Zalewowi informacji, który sprawia, że stajemy się "globalną wioską", towarzyszą bowiem zjawiska budzące niepokój: stres informacyjny - utrata zdolności do selektywnego odbioru treści, uniformizacja poglądów

1 Profesor doktor habilitowany, pracownik naukowy Wydziału Psychologii Uniwersytetu Warszawskiego. Prowadzi badania nad procesem wychowawczym, badania w nurcie psychologii narracyjnej z wykorzystaniem autorskiej metody semantycznej analizy tekstu. Najważniejsze publikacje: Wrastanie w kulturę. Transmisja narracji w wychowaniu rodzinnym (2013), Interakcja wychowawcza (2001). Posiada doświadczenie praktyczne w zakresie grupowych i indywidualnych oddziaływań skierowanych do dzieci, młodzieży, rodzin i nauczycieli, a także w pracy środowiskowej z rodzinami niewydolnymi wychowawczo (dryll@psych. uw.edu.pl). 
połączona z ich postępującym spłycaniem, wirtualizacja kontaktów społecznych ${ }^{2}$. Jak wobec tego Kościół katolicki powinien ustosunkować się do nowych możliwości technicznych? Czy forma przekazu ma wpływa na odbiór? Jaki to wpływ? Ambonę w kościele już dawno zastąpił mikrofon, organy często ustępują miejsca muzyce z płyty lub instrumentów podłączonych do wzmacniacza dźwięku. To nigdy nie budziło wątpliwości ani dyskusji. Czy jednak udogodnienia audiowizualne doskonalą, czy też wypaczają istotę misterium? To, co psycholog może wnieść do dyskusji na ten temat, zawiera się w trzech tezach:

- Treści religijne powinny być przekazywane w okolicznościach autentycznego spotkania uczestników procesu komunikacji. Środki techniczne nie powinny „zasłaniać” osób.

- Obrazowa konkretyzacja, dokonywana w celach dydaktycznych, może uzupełniać, ale nie może zastąpić przekazu werbalnego. Treści religijne można w pełni wyrazić tylko w kodzie symbolicznym - werbalnym.

- Najodpowiedniejszym sposobem konkretyzowania abstrakcyjnych treści wyrażanych w kodzie symbolicznym jest narracja fabularna.

\section{Autentyczne spotkania}

Z perspektywy adresata celem misterium przepowiadania jest przyswojenie Słowa Bożego - jego akceptacja, zrozumienie i uznanie za własne. Nie jest możliwe poznawanie "słowa” wyłącznie na drodze indywidualnych dociekań czy eksperymentów. Tylko doświadczenie społeczne może być jego źródłem.

\footnotetext{
2 M. Ledzińska, Człowiek współczesny w obliczu stresu informacyjnego, Warszawa 2009 .
} 
„Słowo” to znaczenie, a system znaczeń tworzy się, rozwija i zmienia wtedy, kiedy człowiek komunikuje się z drugim człowiekiem.

Sytuacja komunikacyjna najpełniej realizuje się w ramach zdarzenia, w którym osoby są bezpośrednio obecne, dostępne i nawzajem na sobie skoncentrowane - w bezpośrednim dialogu „tu i teraz”. Oczywiście nie każdy dialog wprowadza ważne treści do systemu znaczeń, nie każdy nawet dotyka takich rejonów. Ale o istotności dialogu decyduje nie tylko tematyka. Ważne są także jego okoliczności, mają bowiem wpływ na zaangażowanie różnych instancji poznawczych, aktywnych w procesie percepcji i rozumienia. „Przyswajanie” nie ogranicza się do funkcji intelektu. Odnosi się przede wszystkim do warstwy osobistych ustosunkowań (estetyki, całej sfery motywacyjnej), a szczególnie do poziomu tożsamości, która jest odkrywana i realizuje się w planie społecznym.

Najbogatsze w treść psychologiczną są takie dialogi, które tocząc się we właściwych okolicznościach, angażują zarówno werbalny, jak i niewerbalny przekaz. Wypowiadanym słowom towarzyszy wówczas możliwy do odebrania komentarz emocjonalny. Ten komentarz wyraża ustosunkowanie mówiącego zarówno do wypowiadanych treści, jak i do słuchacza.

Ustosunkowanie do partnera wymiany dialogowej - aspekt relacyjny komunikacji ${ }^{3}$ zazwyczaj nie jest przez rozmówców uświadamiany ani kontrolowany, ale jest rozumiany bardzo adekwatnie. Informacje płyną kanałem niewerbalnym (intonacja, wyraz twarzy, postawa i dynamika ciała) i poprzez kontekst wypowiedzi. Partnerzy wzajemnie „zarażają się" swoim

\footnotetext{
3 G. Bateson, Steps to an ecology mind, New York 1972; L. Grzesiuk, U. Jakubowska, Podejście systemowe, [w:] Psychoterapia: szkoty zjawiska techniki i specyficzne problemy, red. L. Grzesiuk, Warszawa 2002, s. 6o-67.
} 
ustosunkowaniem. Najstaranniej skrywane odcienie niechęci wywołują zwielokrotnioną reakcję zwrotną. Podobnie ustosunkowania pozytywne: szacunek do słuchacza przywołuje szacunek do nadawcy, otwartość otwiera, zaufanie rodzi ufność. Jeżeli informacje przekazywane niewerbalnie pozostają w sprzeczności ze świadomie deklarowanymi intencjami mówiącego, partner dialogu reaguje na niekontrolowany „wyciek” (likage) emocji dających świadectwo prawdzie ${ }^{4}$. Dotyczy to zarówno dialogów prowadzonych w okolicznościach spotkania dwóch lub niewielkiej grupy osób, jak i w okolicznościach dialogu z dużą grupą lub tłumem. Częściowo dotyczy także komunikacji medialnej, z tym że osoba mówiąca do kamery pozbawiona jest możliwości odbierania sygnałów zwrotnych od słuchaczy.

Emocjonalny komentarz treści to najważniejszy czynnik wpływający na gotowość do ich przyswojenia czy chociażby uważnego, refleksyjnego wysłuchania. Komentarz ów buduje konotacyjne znaczenie informacji, określa ich ważność, całe tło i estetykę rozumienia. Ustosunkowanie do treści przekazu także przekazywane jest na drodze empatycznego „zarażania się”. Jeżeli mówiący sam nudzi się tym, co mówi, nie powinien liczyć na odrobinę zainteresowania. Jeżeli „sam nie wierzy w to, co mówi", nawet gdyby jego argumentacja była perfekcyjnie logiczna, spowoduje co najwyżej chłodne, intelektualne rozważanie racji, przesłanek i tez, bez nadziei na ich przyswojenie.

W trakcie liturgii celebrans wypowiada słowa. Również komentuje je, mówiąc kazanie. Cały czas pozostaje w dia$\operatorname{logu}$ z wiernymi. Jeżeli ten dialog będzie autentycznym spotkaniem, pozostanie w pamięci jako przeżycie - stanie się

4 D. B. Bugental, Affective and cognitive processes within threat-oriented family system, [w:] Parental belief system. The psychological consequences for children, eds. I. E. Sigel, A. V. McGillicudy-De Lisi, J. J. Goodnow, Hilsdale NJ 1992, s. 219-243. 
doświadczeniem dotykającym w jakiś sposób najgłębszych warstw systemu znaczeń (utrwali, zmieni, wywoła refleksję, zrodzi nowe pytania, na niektóre odpowie). Jeżeli nie - będzie spektaklem, który może i zostanie zapamiętany ze względu na jakieś nadzwyczajne zabiegi perswazyjne, ale nie dotknie serca.

\section{Konkretyzacje}

W pedagogice teoretycznej XIX w. i w powszechnej praktyce XX-wiecznej szkoły uznaje się, że abstrakcyjne treści nauczania muszą być tak podawane, aby mogły związać się z myśleniem codziennym. W psychologii postulat ów znajduje uzasadnienie. Wiedza gromadzona jest we względnie niezależnych systemach pamięci semantycznej i proceduralnej5. Pamięć proceduralna wynika z działania, zarządza działaniem w sposób bezpośredni, może być werbalizowana, ale wymaga to osobnego procesu intelektualnego. Pamięć semantyczna wywodzi się z przekazów werbalnych - „wiedza z drugiej ręki”, i jest z łatwością odtwarzana w ten sam sposób, ale nie zarządza działaniem. Człowiek bardzo dojrzały sprawnie łączy informacje zgromadzone w obydwu systemach wiedzy, nie jest to jednak automatyczne, wymaga wysiłku. Stąd postulaty, aby dzieciom, w procesie ich nauczania, ułatwiać dostrzeganie związków pomiędzy konkretnymi procedurami działania a zasadami ogólnymi.

Większość teoretyków ${ }^{6}$ przyjmuje, że wiedza konkretna ma donioślejsze znaczenie niż wiedza „scholastyczna”, i nie

\footnotetext{
5 M. Jagodzińska, Psychologia pamięci: badania teorie zastosowania, Gliwice 2008.

6 Por. K. Stemplewska, Wiedza scholastyczna a naturalny rozwój poznawczy, [w:] Wiedza potoczna w szkole, red. E. Dryll, J. Trzebiński, Warszawa 1994, s. 43-85.
} 
docenia zwrotnych relacji pomiędzy obydwoma systemami. Stąd popularność tzw. nauczania problemowego, zamiłowanie do doświadczeń, przykładów i wszelkich form obrazowania. Tylko jeden z wielkich teoretyków zajmujących się rozwojem poznawczym człowieka - Lew Wygotski zwraca uwagę na to, że werbalny przekaz na poziomie abstrakcyjnym poprzedza percepcję, a przez to ukierunkowuje operacje poznawcze na poziomie konkretnym. Nie zawsze zatem uproszczony, konkretny obrazek sprzyja głębszemu rozumieniu abstrakcyjnych treści, a na pewno nie zastępuje ich wykładu.

O adekwatności przekazywania treści abstrakcyjnych (werbalnie) i konkretnych (obrazowo) niewątpliwie przesądza ich pierwotna natura. Prawa fizyki, które wywodzą się z empirii, można łatwo zilustrować, powracając do doświadczenia. Zagadnienia etyczne i inne treści szeroko pojmowanej humanistyki można konkretyzować symbolicznie (kotwiczyć), dokonując swego rodzaju przekładu z jednego kodu komunikacyjnego na inny. Taka symboliczna konkretyzacja (flaga narodowa, krzyż) przywołuje abstrakcyjne pojęcia i aktualizuje ustosunkowania, ale ani ich nie wyjaśnia, ani nie może zastąpić wyjaśnienia. Jest rozumiana, a raczej interpretowana, pod warunkiem istnienia w umyśle reprezentacji tego, co ma przywołać. Inna jest zatem funkcja obrazu. Nie przyczynia się do pogłębienia refleksji, ale angażuje estetycznie (na tyle, na ile jego tworzeniu towarzyszył zamysł artystyczny). Symboliczne obrazowanie konstruuje scenerię, w jakiej dokonuje się międzyludzka wymiana myśli. Oczywiście dzieło sztuki również

\footnotetext{
$7 \quad$ L. Wygotski, Myślenie i mowa, Warszawa 1989; L. Wygotski, The genesis of higher mental functions, [w:] The concept of activity in Soviet psychology, ed. J.V. Wertsch, New York 1981, s. 144-188; L. Wygotski, Narzędzie i znak w rozwoju dziecka, Warszawa 1978.
} 
samo potrafi „mówić”. Wtedy jednak stanowi to pewną upośrednioną (ponad czas i przestrzeń) formę komunikacji społecznej autor-odbiorca, wokół treści, które są tematem dzieła.

Oglądanie obrazka, w porównaniu z czytaniem lub śledzeniem tekstu mówionego, jest prostsze w odbiorze. Obrazy „same wchodzą" w pole bezpośredniej percepcji, przykuwają uwagę mimowolną. Tekst wymaga uwagi dowolnej. Współcześnie w mediach wykorzystywane są techniki oddziaływania bezpośrednio na procesy automatycznego przetwarzania informacji ${ }^{8}$. Niejednokrotnie chociażby w reklamie pożądane jest wręcz chwilowe „wyłączenie” refleksji. Sprzyjają temu takie cechy obrazów, jak: ruch, intensywne barwy, zaskakujące zestawienia dobrze znanych elementów, uśmiechnięte twarze i zgrabne ciała. Ruchome kolorowe obrazy mają silne właściwości stymulacyjne (pobudzenie układu siatkowatego), ale moga być lepiej lub gorzej dostosowane do indywidualnego zapotrzebowania na stymulację. Osoby o wysokim zapotrzebowaniu (mało reaktywne, „twardsze”) wprawiają one w stan optymalnego pobudzenia, zaś osoby o niskim zapotrzebowaniu („delikatne”, bardziej reaktywne) - męczą, dezorganizują i powodują silne pragnienie odcięcia się od źródła bodźców. Optymalny poziom zapotrzebowania na stymulację jest stosunkowo trwałą cechą układu nerwowego o podłożu biologicznym ${ }^{9}$, jednak przyzwyczajenie do przebywania w środowisku o określonych właściwościach stymulacyjnych może tłumić lub wysubtelniać wrażliwość. W sytuacji komunikacyjnej należy się z tym liczyć. Osoba prowadząca dialog,

\footnotetext{
8 D. Maison, Utajone postawy konsumenckie: Analiza możliwości wykorzystania metody TAT, Gdańsk 2004.

9 M. Kofta, Osobowość i różnice indywidualne, [w:] Psychologia: podręcznik akademicki, t. 2: Psychologia ogólna, red. J. Strelau, Gdańsk 2006.
} 
pozostając w kontakcie emocjonalnym z partnerem, ma świadomość poziomu jego pobudzenia sensorycznego. Ta świadomość - wrażliwość na sygnały zainteresowania, chroni przed „zanudzaniem”, ale i przed dezorganizacją poznawczą wynikającą z nadmiaru bodźców. Otoczenie tworzące określoną scenerię przekazu, angażując uwagę, kierunkuje nieświadome procesy przetwarzania w określonych zakresach treści. Czasami jednak rozprasza na tyle, że odbiorca nie może skupić się na tym, co istotne (tak jak w przypadku dzieci z ADHD).

Rozumienie tekstu, w porównaniu z odbiorem materiału obrazowego, opiera się na bardziej skomplikowanych mechanizmach. O ile obraz jest jednoznaczny, przekaz werbalny polega na rekonstrukcji znaczenia. Słowo pozostawia ślad desygnatu, do którego się odnosi. Obraz sam dla siebie jest desygnatem i niczego więcej nie obiecuje. Kod werbalny jest ze swej natury kodem symbolicznym. Ma strukturę systemu, czyli całości, która znaczy, dzięki temu, że w określony sposób są w niej rozmieszczone poszczególne elementy-znaki. Rozumienie znaku wymaga zidentyfikowania jego miejsca w strukturze, a rozumienie struktury możliwe jest dzięki znajomości jednostek znaczących. Mając w tym wprawę, nie odczuwamy trudu realizacji każdego elementarnego procesu rozumienia języka. Można stwierdzić jego obecność, porównując parametry globalne percepcji językowej i obrazowej (np. czasy reakcji). Nie bez przyczyny nauka języka, zarówno ojczystego, jak i obcego, trwa parę lat ${ }^{10}$. Pomimo tego trudu - jednak mówimy. Bo język ludzki to unikalna kompetencja, dzięki której komunikacja społeczna wykracza ponad poziom biologicznego przystosowania. To język sprawia, że doświadczenie jednostek jest

1o Por. E. Clark, First language acquisition, Cambridge 2009. 
przekazywalne kolejnym pokoleniom, stanowi budulec kultury, umożliwia sięganie duchowych warstw egzystencji.

Mówienie i słuchanie (całkowicie sprawne), a szczególnie opowiadanie wymagają zaangażowania wielu funkcji poznawczych: wyobrażeniowych, intelektualnych, estetycznych. Im bardziej abstrakcyjnych tematów dotyczy rozmowa, tym więcej dowolności w procesie rozumienia. Indywidualne struktury sensu każdego człowieka różnią się (mniej lub bardziej). Pokazując komuś obrazek, wiemy, że zobaczyłten właśnie obrazek. Mówiąc, wiemy tylko (na podstawie reakcji mimicznych), czy ma poczucie rozumienia, czy też nie. O tym, jak przekaz został wkomponowany w istniejący u słuchacza system znaczeń, można wnioskować poprzez rekonstrukcję jego perspektywy poznawczej. Rekonstrukcja taka jest łatwiejsza, gdy monolog może być zastąpiony wymianą myśli. Otwarcie się na sygnały informujące o procesie rozumienia automatycznie zmienia w mówiącym „sterowniki” toku wywodu. Trudno precyzyjnie opisać ten proces. W psychoterapii, gdzie podążanie za sposobem myślenia pacjenta ma fundamentalne znaczenie, proporcje mówienia partnerów dialogu są ściśle określone (pacjent 90\%, psycholog 10\%). Przy pomocy niewielu słów terapeuta delikatnie prowadzi proces porządkowania systemu interpretacyjnego pacjenta, pobudzając do aktywności i koniecznego wysiłku intelektualnego.

Im większe zaangażowanie, zarówno w sam odbiór treści werbalnych, jak i w wymianę dialogową, tym większa szansa rozumienia treści będących przedmiotem rozmowy. Pewien wysiłek poznawczy sprawia, że aktywizuje się refleksyjny tryb przetwarzania informacji. Podmiotowe zaangażowanie i refleksja są podstawą przyswajania świadomego i dobrowolnego (a nie automatycznego). Rozbudowuje się struktura sensu, a człowiek zyskuje poczucie, że swoje nowe intelektualne odkrycia akceptuje i uznaje za własne. 
Przekaz (dialog) dokonujący się w trakcie liturgii ma charakter abstrakcyjny. Potrzebny jest pewien stopień ogólnego zaawansowania poznawczego, aby rozpocząć drogę pojmowania treści wiary. Nie są one bowiem kodeksem konkretnych i oczywistych przepisów („myj ręce przed jedzeniem”). Konkretyzacji zasad człowiek musi dokonywać samodzielnie, co wcale nie jest łatwe. Sprzyja temu przewodnictwo osoby bardziej wtajemniczonej, obdarzonej zdolnością decentracji (przyjmowania perspektywy partnera).

Trudność konkretyzacji treści wiary, podobnie jak zagadnień moralnych, polega na tym, że codzienne zdarzenia spostrzegane są $\mathrm{w}$ formie epizodów-fabuł, natomiast zasady formułowane abstrakcyjnie. Już samo nazwanie jakiegoś zachowania „po imieniu”, chociaż doskonale zna się definicję pojęcia, jakiego należałoby użyć, bywa trudne. Jak wiadomo z badań ${ }^{11}$, człowiek bliźnich opisuje w kategoriach moralnych, siebie zaś w kategoriach sprawnościowych. Inaczej interpretuje własne sukcesy, a inaczej porażki ${ }^{12}$. Za to, co uznaje za dobre, gotów jest brać odpowiedzialność, zło zaś tłumaczy okolicznościami albo przypisuje innym. Tego typu zniekształcenia interpretacyjne można pokonać, ćwicząc umiejętność rozdzielania perspektyw samoopisu - bycia jednocześnie podmiotem (opisującym, oceniającym) i przedmiotem (opisywanym). Sprzyja temu opowiadanie fabuł - różnych, także i tych, których głównym bohaterem jest "ja”.

Jezus mówił do ludzi przypowieściami. Opowiadał zdarzenia ilustrujące prawdy, których nauczał. Bohaterami tych opowieści

\footnotetext{
${ }^{11}$ B. Wojciszke, Grzech czy porażka. Moralne i sprawnościowe kategorie w potocznym rozumieniu świata społecznego, [w:] Psychologia rozumienia zjawisk społecznych, red. B. Wojcieszke, M. Jarymowicz, Warszawa-Łódź 1999, s. 153-172. ${ }_{12}$ R. Nisbett, L. Ross, Human inference. Strategies and shortcomings of social judgment, Englewood Cliffs, NJ 1980.
} 
byli ludzie tamtych czasów, działający w scenerii tamtego świata. Opowiadał o drzewach oliwnych, pasterzach i owcach, trędowatych, celnikach i faryzeuszach. Dzisiaj nie ma trędowatych, ale jest choroba i cierpienie. Mało kto podróżował na osiołku. Może nawet nie każdy widział na własne oczy owieczkę. Jest inna scenografia, ale w warstwie znaczeń nie zmieniło się tak wiele. Natura ludzka w dalszym ciągu jest taka, jaką była przed dwoma tysiącami lat. I pomimo powszechnej dostępności informacji praktycznych zagadnienia egzystencjalne (jak i po co żyć) domagają się opowieści.

\section{Narracja}

W rozumieniu literaturoznawczym „narracja” to sposób prezentowania przebiegu zdarzeń w celu zobrazowania pewnego przesłania. Charakterystyczną cechą realistycznej narracji jest uporządkowanie wydarzeń na osi czasu. Jest początek - przedstawienie sytuacji wyjściowej (okoliczności i bohaterów), jest środek - kolejne epizody akcji, i jest zakończenie - efekt działań bohaterów w świecie rządzącym się określonymi prawami. Tekst opowiadany jest zazwyczaj w trzeciej osobie, dzięki czemu narrator pozostaje na zewnątrz stworzonego przez siebie świata. Szczególną logikę tego świata wyraża układ zdarzeń i sposób, w jaki wynikają jedne z drugich. Bohaterowie posiadają jakieś pragnienia, cele, intencje (dobre lub złe), wiedzę, emocje, swoje słabości i cnoty. W kontekście całego opowiadania, w zderzeniu $\mathrm{z}$ jego prawami, intencje te nabieraja szczególnego znaczenia i właśnie to znaczenie stanowi przekaz narracji. W rzeczywistości tekstu reguły dotyczące związków przyczynowych pomiędzy elementarnymi jednostkami akcji podawane są w sposób konkretny (stanowią ich egzemplifikacje). Układ zdarzeń, 
zwłaszcza w optyce zakończenia, umożliwia dokonanie wartościowania, co stanowi chyba najistotniejszą cechę tego typu tekstów. Tak więc narracja to nie tyle samo opowiadanie (treść historii, fabuła), ile raczej perspektywa opowiadania, wyrażająca wartościujące ustosunkowanie podmiotu (autora) wobec przedmiotu (ludzkich poczynań w świecie i praw rządzących tym światem).

Opowiadanie historii w sposób bezpośredni łączy się z codziennym doświadczeniem człowieka. W rozwoju spostrzeganie zdarzeń poprzedza zdolność do spostrzegania reguł ${ }^{13}$. Tym samym zdolność rozumienia opowiadań jest wcześniejsza i bardziej podstawowa niż rozumienia treści abstrakcyjnych ${ }^{14}$. Pierwotna wiedza o prawach rządzących światem społecznym pochodzi z opowiadań, zarówno takich, które dotykają realiów, jak i umiejscowionych w kontekście całkowicie wyobrażonym lub fantastycznym. Każdy element wyobrażonego świata może być utożsamiany z bohaterem-człowiekiem, z którym z kolei identyfikuje się odbiorca.

Narracja fabularna, poza tym, że jest konkretna i możliwa do zrozumienia nawet przez odbiorców bardzo młodych i niedoświadczonych w sprawnym posługiwaniu się abstrakcją, posiada również inne cechy, które wpływają na jej potencjał perswazyjny. W obszarze pamięci semantycznej i werbalnego trybu przetwarzania informacji można wyróżnić odmienne struktury. Ich podziały (nieco różniące się w poszczególnych teoriach) nawiązują do dwóch sposobów rozumienia pojęcia

\footnotetext{
${ }_{13}$ G. Mead, Umyst osobowość społeczeństwo, Warszawa 1975; K. Nelson, Event knowledge. Structure and function in development, Hillsdale 1986; J. Bruner, Actual minds possible worlds, Cambridge, MA 1986.

${ }_{14}$ W. Zagórska, Uczestnictwo młodych dorostych w rzeczywistości wykreowanej kulturowo, Kraków 2004.
} 
"słowo". Jedno z nich tłumaczy się jako logos, drugie jako mythos ${ }^{15}$. To subtelne zróżnicowanie znaczenia pojęcia opisującego struktury semantyczne (parole, w sensie proponowanym przez Ferdinanda de Saussure'a) znajduje w psychologii uzasadnienie. Porządkuje ono bowiem obserwowane odmienności w zakresie wielu funkcji poznawczych - od najprostszych do najbardziej wyrafinowanych. I tak: wyróżnić można dwa tryby spostrzegania: globalny i analityczny ${ }^{16}$, dwa sposoby kodowania informacji: semantyczny sensu stricto i epizodyczny ${ }^{17}$, dwa systemy myślenia: paradygmatyczny i narracyjny ${ }^{18}$, i dwa sposoby konstruowania tekstu: tekst argumentacyjny i tekst narracyjny ${ }^{19}$. Logos to "słowo", którego podstawową funkcją jest funkcja informacyjna. Zgodnie z tradycją nowożytnej myśli europejskiej służy przede wszystkim poznaniu rzeczywistości zewnętrznej, w toku badań weryfikowalnych intersubiektywnie (z ambicjami obiektywizmu). Opiera się na wnioskowaniu podporządkowanym zasadom logiki formalnej, towarzyszy empirii. Jest więc bezosobowe, bezkontekstowe, ahistoryczne.

15 G. Labouvie-Vief, Beyond formal operations. Uses and limit of pure logic in life-span development, „Human Development” 3 (1980), s. 141-162; W. Zagórska, Uczestnictwo mtodych dorostych..., dz. cyt.

16 P. Lindsay, D. Norman, Procesy przetwarzania informacji u człowieka. Wprowadzenie do psychologii, Warszawa 1984.

${ }_{17}$ E. Tulving, Episodic and semantic memory, za: M. Jagodzińska, Psychologia pamięci. Badania, teorie, zastosowania, Gliwice 2008.

18 J. Bruner, Actual minds possible worlds, dz. cyt.

19 J. Bruner, Życie jako narracja, „Kwartalnik Pedagogiczny” 4 (1990), s. 3-17; J. Bartmiński, Tekst jako przedmiot tekstologii lingwistycznej, [w:] Tekst: problemy teoretyczne, red. J. Bartmiński, B. Boniecka, Warszawa 1998, s. 9-25; A. Duszak, Tekst, dyskurs, komunikacja międzykulturowa, Warszawa 1998; A. Wilkoń, Spójność i struktura tekstu, Kraków 2002; B. Witosz, Rozbijanie zastygtych struktur. O tendencjach stylistycznych w tekstach wspótczesnej prozy, [w:] Styl a tekst. Materiały międzynarodowej konferencji naukowej, Opole 26-28.09.1995 r., red. S. Gajda, M. Balowski, Opole 1996, s. 135-141. 
Na poziomie spostrzegania logosowi odpowiada percepcja analityczna, polegająca na precyzyjnym różnicowaniu. Kodowanie opiera się na tworzeniu niesprzecznych systemów informacji, gromadzonych według pewnych reguł organizacyjnych. Myślenie paradygmatyczne to przede wszystkim posługiwanie się logiką. Przykładem tekstu argumentacyjnego może być wywód naukowy.

Mythos to "słowo" osobowe i osobiste. Pełni przede wszystkim funkcje estetyczne. Angażuje wyobraźnię, emocje, wartości. Charakteryzuje je kontekstowość, historyczność, globalność. Opisuje to, co wyjątkowe, indywidualne. Posługuje się środkami wyrazu artystycznego - metafory, sprzeczności, niejednoznaczność, poezja. Nie jest skrępowane zasadami logiki. Służy poznawaniu i przeżywaniu rzeczywistości wewnętrznej. Na poziomie spostrzegania globalna percepcja umożliwia „widzenie między wierszami”. Kodowanie informacji w systemie epizodycznym pozwala pamiętać nastroje, okoliczności, konteksty i ważne połączenia szczegółów. Myślenie narracyjne i opowiadanie narracji tłumaczą świat tak, jak ów świat jawi się w subiektywnym, wewnętrznym przeżyciu.

Doświadczenie estetyczne, jakie powstaje w wyniku kontaktu ze słowem-mythos, jest doświadczeniem głęboko angażującym osobę. Porusza bowiem nie tylko racjonalność, ale i głębsze warstwy psychiki: uczucia, wielomodalną wyobraźnię, ustosunkowania, pamięć zdarzeń, wartościowanie i przede wszystkim odnoszone jest do tożsamości. Paul Ricoeur w lakonicznej wypowiedzi dla „Słowa Powszechnego” zatytułowanej Misja stowa mówi tak: „Spotkanie wydarzeń zgromadzonych w historii organizuje sens. [...] Czytelnik jest wezwany do spojrzenia na swoje życie w świetle wielkich opowiadań stanowiących jego kulturę [...]. [Opowiadanie] ustanawia nowe relacje pomiędzy dobrem a złem, życiem a śmiercią, działaniem 
i doświadczeniem, wolnością a fatum [...] Wątek opowiadania porządkuje wszystkie te elementy w jednym kierunku mythos" ${ }^{20}$.

Jeden z większych psychologów w naszych czasach - Jerome Bruner - napisał, że narracja naśladuje życie, ale i życie naśladuje narrację ${ }^{21}$. Intuicyjnie rozumiemy, że opowiedzieć o czymś to nie to samo, co być uczestnikiem zdarzenia. W rozumieniu potocznym bycie i opowiadanie to dwie odrębne jakości, z których pierwsza jest rzeczywista, druga iluzoryczna. Pierwsza należy do dziedziny bytu, druga do dziedziny świadomości, a „byt określa świadomość”. W stosunku do takiego ujęcia teza Brunera stanowi krok w głąb. „Narracja” i „życie” to wciąż jakości odrębne, ale związek pomiędzy nimi jest obustronny. Opowiadanie relacjonuje wydarzenia, ale my również działamy (tworzymy wydarzenia), kierując się znaczeniami pozostającymi w umyśle pod postacią fabuł. Ta zwrotność relacji nobilituje tekst („świadomość” w porównaniu z „bytem”). Ale w myśleniu o zależnościach wzajemnych pomiędzy słowem a czynem można iść jeszcze dalej. John Austin w swojej teorii aktów mowy pokazuje, że wypowiedź może być czynem - How to do things with words to tytuł jego najsłynniejszej publikacji ${ }^{22}$. Granica pomiędzy działaniem a werbalnym wyrażaniem treści zaciera się.

To zacieranie się granic pomiędzy słowem a czynem oczywiście nie odnosi się do samej fizycznej sfery działań (ruch mięśni itd.). Odnosi się do sfery znaczeń, intencji, wartości. Narracje fabularne, nie tylko te wielkie - wzorcowe, ale również małe i średnie, są w umyśle kodowane w postaci schematów narracyjnych (które są rodzajem skryptów poznawczych) ${ }^{23}$. Skrypt

\footnotetext{
20 P. Ricoeur, Misja stowa, „Przegląd Powszechny” 1 (1994), s. 33-34.

${ }_{21}^{21}$ J. Bruner, Actual minds possible worlds, dz. cyt.

${ }_{22}$ J. Austin, How to do things with words, Harvard 1975.

${ }^{23}$ P. Schank, R. Abelson, Scripts plans goals and understanding, Hilsdale 1977.
} 
to zapis pamięciowy przebiegu zdarzenia, wraz ze wszystkimi jego ważnymi aspektami. Zawiera nie tylko obrazy kolejnych scen, ale i konotacje wartościujące. Obrazy pochodzić mogą zarówno z uogólniania zdarzeń dziejących się w rzeczywistych sytuacjach, jak i z wyobraźni ilustrującej teksty czytanych lub słuchanych opowiadań. Pod względem funkcji regulacyjnej pochodzenie obrazów nie ma znaczenia. Tak samo kierują działaniem zapisy fabuł abstrahowane z doświadczeń życiowych, jak i te, które wywodzą się z opowieści przeżywanych w doświadczeniu estetycznym.

Opowiadając komuś jakąś historię, zwłaszcza w odpowiedni sposób - tak jak rodzice opowiadają dziecku bajkę na dobranoc $^{24}$, wprowadza się lub utrwala w jego osobistym systemie znaczeń skrypty zdarzeń. Wartościuje się i naznacza sensem ludzkie intencje. Pokazuje się świat z jego wewnętrzną logiką. Poucza się, jakie czyny prowadzą do jakich następstw. Wyraża się to wszystko, co czasami tak trudno wyrazić, "prawiąc morały” czy „wygłaszając kazania”. I dlatego właśnie w kazaniu dobrze jest opowiadać historie.

Znaczenie werbalnej komunikacji w misterium Kościoła, a także ważnych, formalnych aspektów komunikacji można oceniać, biorąc za kryterium rozwój religijności człowieka. Istnieje w tym zakresie kilka (niewiele) ujęć teoretycznych ${ }^{25}$. Wszystkie one opisują indywidualną drogę człowieka do Boga. Większość opiera się, podobnie jak teorie rozwoju moralnego, na modelach o rodowodzie poznawczym ${ }^{26}$. Interesującą propozycję innego

\footnotetext{
${ }^{24}$ B. Bettelheim, Cudowne i pożyteczne. O znaczeniach $i$ wartościach baśni, Warszawa 1996.

${ }_{25}$ Duchowy rozwój człowieka. Fazy życia, osobowość, wiara, religijność, red. P. Socha, Kraków 20oo; Cz. Walesa, Rozwój religijności człowieka, t. 1: Dziecko, Lublin 2005 .

${ }_{26}$ J. Piaget, Rozwój ocen moralnych dziecka, Warszawa 1966. L. Kohlberg, Moral
} 
podejścia do tej sprawy przedstawia Romuald Jaworski ${ }^{27}$. Autor ujmuje religijność jako relację interpersonalną między Bogiem a człowiekiem, biorąc za podstawę model komunikacyjny. Ujęcie to wydaje się odkrywcze, bo można w jego ramach dobrze opisywać ścieżki rozwojowe ustosunkowania człowieka do Boga, w odniesieniu do doświadczeń społecznych.

Relacja interpersonalna kształtowana jest przez indywidualne wkłady partnerów, którzy w niej uczestniczą. Obok rozlicznych uwarunkowań sytuacyjnych na jej ostateczny kształt ma wpływ pewien indywidualny styl wchodzenia w relacje. Są osoby bardziej otwarte i zamknięte, są ufający i nieufni, narzucający „swoje” i pokorni, którzy umieją i pragną słuchać. Indywidualny styl wchodzenia w relacje może mieć bardziej formalny lub bardziej osobowy charakter. Formalny charakter przejawia się w drobiazgowym przestrzeganiu etykiety, ograniczaniu przekazu własnych ustosunkowań, traktowaniu partnera przede wszystkim ze względu na jego rolę społeczną. Osobowy charakter relacji wyznacza ukierunkowanie na subiektywność. Nie chodzi tylko o to, aby poinformować, zapytać, pokazać samego siebie lub załatwić jakąśs sprawę. Celem zdarzenia interakcyjnego w relacji osobowej jest spotkanie i doświadczenie „bycia razem” w jakimś fragmencie rzeczywistości wspólnej. Spotkanie takie jest kreacją, dlatego wymaga koncentracji uwagi, zaangażowania, skupienia na treści i partnerze. Autentyczne spotkanie uobecnia treści (eksternalizuje, obiektywizuje). One się stają pomiędzy ludźmi. I są.

stages and moral development, [w:] Moral development and behavior, ed. T. Lickona, New York 1976, s. 31-53.

${ }_{27}$ R. Jaworski, Model rozwoju indywidualnej religijności jako relacji interpersonalnej między Bogiem a człowiekiem, referat na śródrocznym seminarium Sekcji Psychologii Rozwojowej PTP, 11.02.2010, Warszawa 2010 (UKSW). 
Styl wchodzenia w relacje osobowe zmienia się pod wpływem doświadczeń. Prototypowe znaczenie w jego rozwoju mają interakcje z rodzicami i autorytetami. Wśród autorytetów znajdują się ci, którzy opowiadają o Bogu - Jego rzecznicy i reprezentanci. Z tego względu modelowanie relacji osobowej w Kościele może mieć wpływ na jakość wkładu człowieka w relację z Bogiem. W czasie liturgii nie ma miejsca na zindywidualizowany dialog dwóch osób. Dialog toczy się pomiędzy księdzem a wiernymi, a ich role są zróżnicowane. Wyraźniejszy wkład i większy wpływ na jakość tego dialogu (a zatem i większą odpowiedzialność) ma osoba prowadząca ksiądz.

Prowadzenie dialogu z grupą, nawet wtedy (a może „zwłaszcza wtedy") gdy grupa, z racji roli, oczekuje prowadzenia, jest sztuką. Jak każda dziedzina sztuki, także i to nie do końca poddaje się opisowi, a reguły nie są jednoznaczne. W zasadzie wszystko - również używanie środków technicznych może okazać się adekwatne albo śmieszne czy niestosowne. O adekwatności formy można mówić wtedy, kiedy kreacja stanowi spójny wewnętrznie przekaz, podporządkowany treści i przesłaniu. Forma nie powinna jednak zbytnio angażować sobą. Doświadczone krawcowe mówią zawsze, że sukienka jest dobrze uszyta, kiedy idąc w niej ulicą, można usłyszeć „piękna kobieta”, a nie „piękna sukienka”. Tutaj jest podobnie.

\section{Bibliografia}

Austin J., How to do things with words, Harvard 1975.

Bartmiński J., Tekst jako przedmiot tekstologii lingwistycznej, [w:] Tekst: problemy teoretyczne, red. J. Bartmiński, B. Boniecka, Warszawa 1998, s. 9-25. 
Bateson G., Steps to an ecology mind, New York 1972.

Bettelheim B., Cudowne i pożyteczne. O znaczeniach $i$ wartościach baśni, Warszawa 1996.

Bruner J., Actual minds possible worlds, Cambridge, MA 1986.

Bruner J., Życie jako narracja, „Kwartalnik Pedagogiczny” 4 (1990), S. $3-17$.

Bugental D. B., Affective and cognitive processes within threat-oriented family system, [w:] Parental belief system. The psychological consequences for children, eds. I. E. Sigel, A. V. McGillicudy-De Lisi, J. J. Goodnow, Hilsdale, NJ 1992, s. 219-243.

Clark E., First language acquisition, Cambridge 2009.

Duchowy rozwój człowieka. Fazy życia osobowość wiara religijność, red. P. Socha, Kraków 2000.

Duszak A., Tekst, dyskurs, komunikacja międzykulturowa, Warszawa 1998.

Grzesiuk L., Jakubowska U., Podejście systemowe, [w:] Psychoterapia: szkoty, zjawiska, techniki i specyficzne problemy, red. L. Grzesiuk, Warszawa 2002, s. 60-67.

Jagodzińska M., Psychologia pamięci. Badania, teorie, zastosowania, Gliwice 2008.

Jaworski R., Model rozwoju indywidualnej religijności jako relacji interpersonalnej między Bogiem a człowiekiem, referat na śródrocznym seminarium Sekcji Psychologii Rozwojowej PTP, 11.02.2010, Warszawa (UKSW).

Kofta M., Osobowość i różnice indywidualne, [w:] Psychologia. Podręcznik akademicki, t. 2: Psychologia ogólna, red. J. Strelau, Gdańsk 2006.

Kohlberg L., Moral stages and moral development, [w:] Moral development and behavior, ed. T. Lickona, New York 1976, s. 31-53.

Labouvie-Vief G., Beyond formal operations. Uses and limit of pure logic in life-span development, „Human Development” 3 (1980), s. $141-162$. 
Ledzińska M., Człowiek wspótczesny w obliczu stresu informacyjnego, Warszawa 2009.

Lindsay P., Norman D., Procesy przetwarzania informacji u człowieka. Wprowadzenie do psychologii, Warszawa 1984.

Maison D., Utajone postawy konsumenckie. Analiza możliwości wykorzystania metody TAT, Gdańsk 2004.

Mead G., Umyst, osobowość, społeczeństwo, Warszawa 1975.

Nelson K., Event knowledge. Structure and function in development, Hillsdale 1986.

Nisbett R., Ross L., Human inference. Strategies and shortcomings of social judgment, Englewood Cliffs, NJ 1980.

Piaget J., Rozwój ocen moralnych dziecka, Warszawa 1966.

Ricoeur P., Misja stowa, „Przegląd Powszechny” 1 (1994), s. 2-40.

Schank P., Abelson R., Scripts plans goals and understanding, Hilsdale 1977.

Stemplewska K., Wiedza scholastyczna a naturalny rozwój poznawczy, [w:] Wiedza potoczna w szkole, red. E. Dryll, J. Trzebiński, Warszawa 1994, s. 43-85.

Walesa Cz., Rozwój religijności człowieka, t. 1: Dziecko, Lublin 2005.

Wilkoń A., Spójność i struktura tekstu, Kraków 2002.

Witosz B., Rozbijanie zastygtych struktur. O tendencjach stylistycznych w tekstach wspótczesnej prozy, [w:] Styl a tekst. Materiaty międzynarodowej konferencji naukowej, Opole 26-28.09.1995 r., red. S. Gajda, M. Balowski, Opole 1996, s. 135-141.

Wojciszke B., Grzech czy porażka. Moralne i sprawnościowe kategorie w potocznym rozumieniu świata społecznego, [w:] Psychologia rozumienia zjawisk spotecznych, red. B. Wojcieszke, M. Jarymowicz, Warszawa-Łódź 1999, s. 153-172.

Wygotski L., Myślenie i mowa, Warszawa 1989.

Wygotski L., The genesis of higher mental functions, [w:] The concept of activity in Soviet psychology, ed. J. V. Wertsch, New York 1981, S. 144-188. 
Wygotski L., Narzędzie i znak w rozwoju dziecka, Warszawa 1978.

Zagórska W., Uczestnictwo młodych dorosłych $w$ rzeczywistości wykreowanej kulturowo, Kraków 2004. 
A* Uniwersytet Papieski 